\title{
SURVEY THE ALLELOPATHIC EFFECTS OF TOBACCO (NICOTIANA TABACUM L.) ON CORN (ZEA MAYS L.) GROWTH AND GERMINATION
}

\author{
M. KHOSHKHARAM ${ }^{1}$, M.H. SHAHRAJABIAN ${ }^{1,2,3^{*}}$, W. SUN ${ }^{2,3}$, Q. CHENG ${ }^{2,3}$ \\ *E-mail: hesamshahrajabian@gmail.com
}

Received: Sept. 26, 2019. Revised: Nov. 06, 2019. Accepted: Nov. 18, 2019. Published online: Mar. 06, 2020

\begin{abstract}
Allelopathy is the direct influence of chemical released from one plant on the development and growth of another plant. The trial accomplished in seed technology laboratory of Faculty of Agriculture, Islamic Azad University of Isfahan, in 2018. A factorial layout within completely randomized design with four replications was used. Treatments included plant organs extract (leaf, stem, root and total plant), and different tobacco extract densities includes four levels of $0 \%, 25 \%, \quad 50 \%$ and $100 \%$. Control treatment $(0 \%$ of tobacco extract $)$ had obtained the highest value of germination rate, germination percentage, coleoptile weight, radicle weight, radicle length and coleoptile length. The maximum germination rate, germination percentage, coleoptiles weight, radicle weight, radicle length and coleoptiles length was related to extract of stem extract which had meaningful differences with other treatments. Both radicle and coleoptile
\end{abstract}

length decreased with increase in concentration of tobacco extract. Tobacco extract has negatively effects on corn seeds by decreasing the germination rate. Tobacco may increase the presence of secondary metabolites, such as alkaloids, all of which may have different effects on seed germination percentage. The highest germination percentage (91.91\%), coleoptile weight $(0.046 \mathrm{mg})$, radicle weight $(0.0161 \mathrm{mg})$, radicle length $(7.24$ $\mathrm{mm})$, and coleoptiles length $(6.45 \mathrm{~mm})$ was related to interaction between control treatment $(0 \%$ of extract) and stem extract. It is concluded that the extract of Nicotiana tabacum had both inhibitory and stimulatory effects on seedling growth of Zea mays.

Keywords: radicle length; radicle weight; organ extract; coleoptile length; coleoptile weight.

\footnotetext{
${ }_{1}^{1}$ Department of Agronomy and Plant Breeding, Isfahan (Khorasgan) Branch, Islamic Azad University, Iran

2 Biotechnology Research Institute, Chinese Academy of Agricultural Sciences, Beijing, China

${ }^{3}$ Nitrogen Fixation Laboratory, Qi Institute, Jiaxing, Zhejiang, China
} 


\section{ALLELOPATHIC EFFECTS OF TOBACCO ON CORN GROWTH AND GERMINATION}

\section{INTRODUCTION}

Corn (Zea mays L.) is an important annual cereal and it is the third important food crop in the world (Broumand et al., 2010; Khoshkharam et al., 2010; Esfandiary et al., 2011; Soleymani etal., 2011; Esfandiary et al., 2012; Soleymani and Shahrajabian, 2012a,b; Soleymani et al., 2012a,b; Soleymani and Shahrajabian, 2013; Soleymani et al., 2016; Shahrajabian et al., 2017). Plants secrete different types of secondary metabolites, which influence the growth and development of the surrounding plants and microbes by a process called allelopathy, which plays a significant role in agroecosystems, and affects the growth, quality and quantity of the produce (Ogbaji et al., 2013; Norouzi et al., 2016: Shahrajabian et al., 2019a,b,c,d). Allelopathy is an interference mechanism in which living or dead plants release allelochemicals exerting an effect on the associated plants, and can play an important role in natural ecosystems (Inderjit and Duke, 2003; Ahmad and Bano, 2013). Ahmad and Bano (2013) reported the delay and reduction of seeds germination and inhibition of root and shoot growth because allelochemicals. Soleymani and Shahrajabian (2018) also reported that germination is the most sensitive stage in the life cycles of plant and uniform germination is essential to having increase in the yield. Tobacco plant is rich in allelochemicals, including isoprenoids, alkaloids, cinnamoylputrescines, flavonoids and anthocyanins (Nugroho and Verpoorte, 2002; Farooq et al., 2014). Mushtaq and Siddiqui (2018) found that delayed seed germination and slow root growth, attributable to the extracts, maybe baffled with diffusion effects on the rate of imbibition, delayed initiation of germination and particularly cell elongation.

Farooq et al. (2014) has found that allelopathic chemicals from tobacco negatively impacts mung bean growth. Therefore, the objective of the present studies was to investigate the allelopathic effect of tobacco (Nicotiana tabacum L.) on germination and early growth of corn.

\section{MATERIAL AND METHODS}

This research accomplished in seed technology laboratory of Faculty of Agriculture, Islamic Azad University of Isfahan, Iran, in 2018 (latitude $32^{\circ} 40$ N, longitude $51^{\circ} 58^{\prime} \mathrm{E}$ and $1570 \mathrm{~m}$ elevation). A factorial layout within completely randomized design with four replications was used. Treatments included plant organs extract (leaf, stem, root and total) and different tobacco extract densities (Burley cultivar) includes four levels of $0 \%, 25 \%, 50 \%$ and $100 \%$. Aerial sections of the plant were separated by scissors. Aerial sections and roots were dried and grind. The achieved $5 \mathrm{~g}$ powder has been poured in $100 \mathrm{ml}$ water and has been put during $24 \mathrm{hrs}$ on shaker machine. Then, it was put in centrifuge machine during 15 min with 3000 rotations. The result mixture was filtered by Whatman filter paper (number 2). At first, the seeds of corn (SC 704) were put in sodium hypocoloid 5\% during $10 \mathrm{~min}$ and then they were washed by distilled water. Seeds soaked in distilled water were used 


\section{KHOSHKHARAM, M.H. SHAHRAJABIAN, W. SUN, Q. CHENG}

as control treatment. For germination test, 20 seeds were put in $12 \mathrm{~cm}$ Petri dishes on two layers of filter paper and $5 \mathrm{ml}$ of distilled water for control and $5 \mathrm{ml}$ from levels of expected extract were added to it. The lids of containers with the temperature $25^{\circ} \mathrm{C}$ were prepared (12 hrs in the day and $12 \mathrm{hrs}$ in the night). Every day, the germinated seeds were numbered in the certain hour. The criterion of radical exit germination has been considered $1 \mathrm{~mm}$. At the end of germination test, the length of radical and coleoptiles were measured. Both radical length (root) and plumule (shoot) length was measured using a ruler in $\mathrm{cm}$. Also, at the end, the extreme percent of germination and the rate of germination were accounted. For counting the length of radical and coleoptiles, 10 germinated seeds were sent out from Petri dishes and measured. For accounting germination rate, from the second day, unit when the seeds did not germinate, the germinated seeds were counted per $24 \mathrm{hrs}$ and on time.

The germination rate was defined as following (Equation 1):

$$
G R=\Sigma \frac{\mathrm{N}}{\Sigma(n \times g)}
$$

where, $n$ is the number of germinated seed on growth day and $g$ is the number of germination seeds. Analysis of variance (ANOVA) was used to determine the significant differences. The Multiple Range Test of Duncan performed the separation means $(P<0.05)$. All statistics was performed with the SAS statistical software.

\section{RESULTS AND DISCUSSION}

The influence of tobacco extract was significant on coleoptiles weight and coleoptiles length, but germination rate, germination percentage, radical weight and length were not significantly affected by it. Soleymani and Shahrajabian (2012c) also reported the significant influence of sesame extract density on germination rate, germination percentage, coleoptiles weight, radical and coleoptile length. Plant organs had meaningful effect on germination rate, germination percentage, coleoptiles weight, radical weight, radical length, and coleoptiles length.

Soleymani and Shahrajabian (2012c) also mentioned the meaningful effect of plant organ on germination rate, radical weight, radical length and coleoptiles length. The interaction between tobacco extract and plants organs had no meaningful effect on experimental characteristics (Table 1).

Yazdani and Bagheri (2011) demonstrated that germination percentage, root and shoot length in soybean in both laboratory and glasshouse experiment were significantly affected by different tobacco root and shoot extracts.

The highest germination rate $(2.48 \%)$, and germination percentage $(78.48 \%)$ was related to control treatment, followed by $25 \%, 50 \%$ and $100 \%$ of tobacco extract density. All differences between treatments on germination rate and germination percentage were not significant.

Baek et al. (2017) concluded that allelopathic chemicals released by tobacco have detrimental effects on the germination of mung bean and red fife wheat. The maximum coleoptiles weight $(0.037 \mathrm{mg})$ and the minimum 


\section{ALLELOPATHIC EFFECTS OF TOBACCO ON CORN GROWTH AND GERMINATION}

one $(0.027 \mathrm{mg})$ was obtained for control treatment $(0 \%)$ and $100 \%$ of tobacco extract density, which had meaningful differences with each other.

Table 1 - Analysis of variance for experimental characteristics

\begin{tabular}{|c|c|c|c|c|c|c|c|}
\hline S.O.V & d.f. & $\begin{array}{l}\text { Germi- } \\
\text { nation } \\
\text { rate }\end{array}$ & $\begin{array}{l}\text { Germi- } \\
\text { nation } \\
\text { percen- } \\
\text { tage }\end{array}$ & $\begin{array}{l}\text { Cole- } \\
\text { optile } \\
\text { weight }\end{array}$ & $\begin{array}{l}\text { Radicle } \\
\text { weight }\end{array}$ & $\begin{array}{l}\text { Radicle } \\
\text { length }\end{array}$ & $\begin{array}{l}\text { Cole- } \\
\text { optile } \\
\text { length }\end{array}$ \\
\hline Replication & 2 & 0.938 & 35.592 & 0.000026 & 0.00000001 & 0.203 & 0.163 \\
\hline $\begin{array}{l}\text { Tobacco } \\
\text { extract (a) }\end{array}$ & 3 & $0.281^{\mathrm{ns}}$ & $111.302^{\text {ns }}$ & $0.00028^{*}$ & $0.00000425^{\mathrm{ns}}$ & $0.575^{\mathrm{ns}}$ & $3.173^{*}$ \\
\hline $\begin{array}{l}\text { Plant } \\
\text { organs (b) }\end{array}$ & 3 & $14.619^{* *}$ & $2029.228^{\star *}$ & $0.000617^{* *}$ & $0.00023168^{* *}$ & $4.836^{\star *}$ & $11.053^{* *}$ \\
\hline$a \times b$ & 9 & $0.689^{\text {ns }}$ & $101.614^{\mathrm{ns}}$ & $0.00005^{\mathrm{ns}}$ & $0.00000122^{\mathrm{ns}}$ & $0.54^{\mathrm{ns}}$ & $1.298^{\mathrm{ns}}$ \\
\hline Error & 30 & 1.629 & 67.187 & 0.00004 & 0.00000187 & 0.312 & 0.655 \\
\hline
\end{tabular}

There were no significant differences between $100 \%$ of tobacco extract with $25 \%$ and $50 \%$ of extract density. Radicle weight decreased from control treatment o application $100 \%$ of tobacco extract density, but there were no significant differences between treatments. Radicle weight in $0 \%, 25 \%, 50 \%$ and $100 \%$ of tobacco extract was $0.0094 \mathrm{mg}, 0.0089 \mathrm{mg}$, $0.0084 \mathrm{mg}$, and $0.0080 \mathrm{mg}$, respectively. The higher value for radical length was achieved in application of $0 \%$ of tobacco extract (control treatment) (6.49 $\mathrm{mm})$, followed by $25 \%(6.22 \mathrm{~mm}), 50 \%$ $(6.05 \mathrm{~mm})$ and $100 \%(6.01 \mathrm{~mm})$ application of tobacco extract density. Moreover, all differences were not significant between treatments. The result of this research is in agreement with Stachon et al. (1980) and Akpan et al. (2017), which reported that the extracts of allelopathic plants had more inhibitory effect on the root growth than hypocotyls growth because root is the first organ to absorb allelochemical from the environment.

The highest and the lowest value of coleoptiles length was related to $0 \%$ (control treatment $(4.94 \mathrm{~mm})$, and $25 \%$ of tobacco extract density $(3.90 \mathrm{~mm})$, which had significant difference with each other.

There was no meaningful difference between application of $25 \%$ and $50 \%$ of tobacco extract density (Table 2). Unlike the results of this experiment, Akpan et al. (2017) reported that there was no significant difference in plumule length of corn and it was not significantly affected by the extracts of L. clavatum.

Nishida et al. (2005) also concluded that the permeability of allelochemicals to root tissue was greater than that of shoot tissue. The 


\section{KHOSHKHARAM, M.H. SHAHRAJABIAN, W. SUN, Q. CHENG}

highest germination rate was related to stem extract $(3.62 \%)$, which had meaningful difference with all other treatments, except stem extract. Germination rate in leaf, root and total extract was $1.94 \%, 2.79 \%$ and $1.06 \%$, respectively.
Singh et al. (2009) also observed that the allelochemicals present in the aqueous leachate of Nicotiana plumbaginifolia Viv. delayed germination and reduced seedling growth of Zea mays L.

Table 2 - Mean comparison of germination rate (\%), germination percentage $(\%)$, coleoptile weight $(\mathrm{mg})$, radical weight $(\mathrm{mg})$, radical length $(\mathrm{mm})$ and coleoptile length $(\mathrm{mm})$

\begin{tabular}{|c|c|c|c|c|c|c|}
\hline Treatment & $\begin{array}{l}\text { Germination } \\
\text { rate }\end{array}$ & $\begin{array}{l}\text { Germination } \\
\text { percentage }\end{array}$ & $\begin{array}{l}\text { Coleoptile } \\
\text { weight }\end{array}$ & $\begin{array}{l}\text { Radicle } \\
\text { weight }\end{array}$ & $\begin{array}{l}\text { Radicle } \\
\text { length }\end{array}$ & $\begin{array}{l}\text { Coleoptile } \\
\text { length }\end{array}$ \\
\hline \multicolumn{7}{|c|}{ Tobacco extract density (E) } \\
\hline $0 \%(\mathrm{E} 1)$ & $2.48^{\mathrm{a}}$ & $78.48^{\mathrm{a}}$ & $0.037^{\mathrm{a}}$ & $0.0094^{\mathrm{a}}$ & $6.49^{\mathrm{a}}$ & $4.94^{\mathrm{a}}$ \\
\hline $25 \%(E 2)$ & $2.45^{\mathrm{a}}$ & $73.7^{\mathrm{a}}$ & $0.028^{b}$ & $0.0089^{a}$ & $6.22^{a}$ & $3.9^{b}$ \\
\hline $50 \%(\mathrm{E} 3)$ & $2.33^{\mathrm{a}}$ & $73.56^{\mathrm{a}}$ & $0.028^{b}$ & $0.0084^{\mathrm{a}}$ & $6.05^{a}$ & $4.22^{b}$ \\
\hline $100 \%(E 4)$ & $2.14^{\mathrm{a}}$ & $71.22^{\mathrm{a}}$ & $0.027^{b}$ & $0.0080^{\mathrm{a}}$ & $6.01^{\mathrm{a}}$ & $4.9^{\mathrm{a}}$ \\
\hline \multicolumn{7}{|c|}{ Plant organs $(\mathrm{O})$} \\
\hline Leaf (01) & $1.94^{\mathrm{bc}}$ & $68.22^{\mathrm{C}}$ & $0.026^{\mathrm{C}}$ & $0.0064^{\mathrm{C}}$ & $6^{b}$ & $3.97^{\mathrm{C}}$ \\
\hline Root (O2) & $2.79^{\mathrm{ab}}$ & $80.56^{b}$ & $0.033^{b}$ & $0.008^{b}$ & $6.30^{b}$ & $4.83^{b}$ \\
\hline Stem (O3) & $3.62^{a}$ & $88.77^{\mathrm{a}}$ & $0.039^{\mathrm{a}}$ & $0.015^{\mathrm{a}}$ & $6.99^{a}$ & $5.66^{a}$ \\
\hline Total (O4) & $1.06^{\mathrm{C}}$ & $59.41^{\mathrm{d}}$ & $0.023^{\mathrm{C}}$ & $0.0052^{\mathrm{d}}$ & $5.47^{c}$ & $3.49^{c}$ \\
\hline \multicolumn{7}{|l|}{$\mathrm{E} \times \mathrm{O}$} \\
\hline E1O3 & $3.79^{\mathrm{a}}$ & $91.91^{\mathrm{a}}$ & $0.046^{\mathrm{a}}$ & $0.0161^{\mathrm{a}}$ & $7.24^{\mathrm{a}}$ & $6.45^{\mathrm{a}}$ \\
\hline E1O2 & $2.53^{\mathrm{abc}}$ & $79.46^{\mathrm{abcd}}$ & $0.037^{\mathrm{abc}}$ & $0.0079^{\text {cd }}$ & $6.21^{\mathrm{bc}}$ & $5.48^{\mathrm{abc}}$ \\
\hline E1O1 & $2.01^{\mathrm{abc}}$ & $74.02^{\text {bcde }}$ & $0.033^{\text {bcd }}$ & $0.007^{\text {cdef }}$ & $6.19^{b c}$ & $4.16^{\mathrm{cde}}$ \\
\hline E1O4 & $1.59^{\mathrm{abc}}$ & $68.51^{\text {cdef }}$ & $0.032^{\text {bcd }}$ & $0.0064^{\text {defg }}$ & $6.31^{b c}$ & $3.67^{\text {de }}$ \\
\hline E2O3 & $3.41^{\mathrm{ab}}$ & $91.08^{\mathrm{a}}$ & $0.043^{a b}$ & $0.0160^{a}$ & $7.17^{\mathrm{a}}$ & $6.05^{\mathrm{ab}}$ \\
\hline E2O2 & $2.95^{\mathrm{abc}}$ & $86.18^{a b}$ & $0.033^{\text {bcd }}$ & $0.0085^{c}$ & $6.74^{\mathrm{ab}}$ & $4.49^{\mathrm{cd}}$ \\
\hline E2O1 & $2.49^{\mathrm{abc}}$ & $62.44^{\mathrm{efg}}$ & $0.019^{\text {ef }}$ & $0.0059^{\text {efgh }}$ & $5.89^{C}$ & $2.85^{\mathrm{ef}}$ \\
\hline E2O4 & $0.96^{\mathrm{bc}}$ & $55.12^{\mathrm{fg}}$ & $0.015^{\dagger}$ & $0.0052^{\text {fgh }}$ & $5.08^{d}$ & $2.2^{\dagger}$ \\
\hline E3O3 & $3.31^{\mathrm{ab}}$ & $81.31^{\mathrm{abc}}$ & $0.033^{\mathrm{bcd}}$ & $0.0142^{b}$ & $6.4^{\mathrm{bc}}$ & $4.83^{\mathrm{bcd}}$ \\
\hline E3O2 & $2.69^{\mathrm{abc}}$ & $77.21^{\text {abcde }}$ & $0.031^{\text {bcde }}$ & $0.0076^{\mathrm{cde}}$ & $6.04^{c}$ & $4.39^{\text {cd }}$ \\
\hline E3O1 & $2.32^{\mathrm{abc}}$ & $72.32^{\text {bcde }}$ & $0.027^{\text {cde }}$ & $0.0069^{\text {cdef }}$ & $6.05^{c}$ & $4.1^{\text {cde }}$ \\
\hline E3O4 & $1.01^{\mathrm{bc}}$ & $63.42^{\text {efg }}$ & $0.021^{\mathrm{def}}$ & $0.0048^{g h}$ & $5.71^{c}$ & $3.54^{\text {def }}$ \\
\hline E4O3 & $3.99^{\mathrm{a}}$ & $90.79^{a}$ & $0.032^{\text {bcd }}$ & $0.0139^{b}$ & $7.15^{\mathrm{a}}$ & $5.33^{\mathrm{abc}}$ \\
\hline $\mathrm{E} 4 \mathrm{O} 2$ & $2.98^{\mathrm{abc}}$ & $79.4^{\mathrm{abcd}}$ & $0.029^{\text {cde }}$ & $0.0079^{c d}$ & $6.21^{\mathrm{bc}}$ & $4.95^{\mathrm{abcd}}$ \\
\hline E4O1 & $0.94^{\mathrm{bc}}$ & $64.08 d^{\text {efg }}$ & $0.023^{\text {def }}$ & $0.0058^{\text {efgh }}$ & $5.88^{C}$ & $4.78^{\mathrm{bcd}}$ \\
\hline E4O4 & $0.67^{c}$ & $50.6^{9}$ & $0.022^{\text {def }}$ & $0.0044^{h}$ & $4.78^{d}$ & $4.55^{\mathrm{bcd}}$ \\
\hline
\end{tabular}

Common letters within each column do not differ significantly.

$\mathrm{E}=$ Tobacco extract, $\mathrm{O}=$ Plant organ 


\section{ALLELOPATHIC EFFECTS OF TOBACCO ON CORN GROWTH AND GERMINATION}

The highest value of germination percentage was obtained for stem extract $(88.77 \%)$, which had meaningful differences with other treatments. Germination percentage in leaf, root and total extract was $68.33 \%, \quad 80.56 \%$ and $59.41 \%$, respectively. Furthermore, all differences between other treatments were significant.

Florentine and Westbrooke (2005) also reported that aqueous extract of tobacco shoots have inhibitory effects on growth and germination of some crops.

The maximum coleoptiles weight $(0.39 \mathrm{mg})$ and radical weight $(0.0150 \mathrm{mg})$ was achieved in stem extract, and the minimum one was related to total extract. Coleoptile weight and radical weight in total extract was $0.023 \mathrm{mg}$ and $0.0052 \mathrm{mg}$, respectively. The higher value of radical length was related to stem extract $(6.99 \mathrm{~mm})$, followed by root $(6.30 \mathrm{~mm})$, leaf $(6.00 \mathrm{~mm})$, and total extract $(5.47 \mathrm{~mm})$, respectively. All differences between treatments were meaningful. The maximum coleoptile length was related to stem extract $(5.66 \mathrm{~mm})$, which had significant difference with total extract $(3.49 \mathrm{~mm})$. Coleoptile length in leaf and root extract was $3.97 \mathrm{~mm}$, and $4.83 \mathrm{~mm}$, respectively. All differences between treatments were significant (Table 2). Nekonam et al. (2014) and Norouzi et al. (2016) found that all aqueous extracts from $N$. tabacum showed a significant inhibitory effect on the germination, seedling length and weight of redroot pigweed plants. $\begin{array}{ccr}\text { The } & \text { highest } & \text { germination } \\ \text { percentage } & (91.91 \%) & \text { coleoptile }\end{array}$ weight $(0.046 \mathrm{mg})$, radicle weight $(0.0161 \mathrm{mg})$, radicle length $(7.24 \mathrm{~mm})$ and coleoptiles length $(6.45 \mathrm{~mm})$ was related to interaction between control treatment $(0 \%$ of extract) and stem extract. The interaction between $100 \%$ of extract and total plant organ extract has obtained the higher value of germination rate $(3.99 \%)$, compared to those of other treatments (Table 2).

\section{CONCLUSIONS}

Allelopathic compounds, often considered as plant produced herbicides, can inhibit growth of nearby plants. Allelochemicals produced by one crop species can influence the growth, productivity and yield of other crops of the same crop. These noxious chemicals influence target species in different ways; affecting growth of root and shoot, they may interfere nutrient uptake or they can attack a naturally occurring symbiotic relationship thereby destroying the plant's usable source. Control treatment $(0 \%$ of tobacco extract) had obtained the highest value of germination rate, germination percentage, coleoptiles weight, radicle weight, radicle length and coleoptile length. The maximum germination rate, germination percentage, coleoptiles weight, radicle weight, radicle length and coleoptiles length was related to extract of stem, which had meaningful differences with other treatments. The results clearly showed that tobacco extracts inhibited seed 


\section{KHOSHKHARAM, M.H. SHAHRAJABIAN, W. SUN, Q. CHENG}

germination, root and shoot growth of corn. Given the fact that environmental conditions in the field can be different from results in laboratory and greenhouse, so additional researches are required to evaluate the allelopathic influence under different field conditions.

\section{REFERENCES}

Ahmad, N. \& Bano, A. (2013). Impact of allelopathic potential of maize (Zea mays L.) on physiological and growth of soybean (Glycine max (L.) Merr.). Pak.J.Bot., 45(4): 1187-1192. Available at: http://www.pakbs.org

Akpan, E.N., Denise, E.M., Ezendiokwelu, E.L. \& Anyadike, M.C. (2017). Growth response of seedlings of Zea mays (L.) to aqueous extract of Lycopodium clavatum (L.). MOJ Biol.Med., 7(2): 287-289. DOI: 10.15406/mojbm. 2017.02.00058

Baek, J.M., Kawecki, O.J., Lubin, K.D., Song, J., Wiens, O.A. \& Wu, F. (2014). Allelopathic effects of Nicotiana tabacum on the germination of Vigna radiata and Triticum aestivum. WURJHNS, 8(1): 1-5, DOI: 10.5206/wurjhns.2017-18.1

Broumand, P., Rezaei, A., Soleymani, A., Shahrajabian, M.H. \& Noory, A. (2010). Influence of forage clipping and top dressing of nitrogen fertilizer on grain yield of cereal crops in dual purpose cultivation system. Res. on Crops, 11(3): 603-613

Esfandiary, M., Soleymani, A., Shahrajabian, M.H. \& Darkhal, H. (2011). Effect of planting methods on grain yield and leaf orientation at different stages of corn cultivars. Res. on Crops, 12(2):336-340. Available at: Google Scholar

Esfandiary, M., Soleymani, A. \& Shahrajabian, M.H. (2012).
Evaluation of yield and yield components of corn cultivars in different planting methods under semi arid condition of Iran. JFAE, 10(2): 664-667. Available at: Google Scholar

Farooq, M., Hussain, T., Wakeel, A. \& Cheema, Z.A. (2014). Differential response of maize and mungbean to tobacco allelopathy. Exp.Agric., 50(4): 611-624, DOI: 10.1017/S00 14479714000106. Available at: https://www.cambridge.org

Florentine, S.K. \& Westbrooke, M.E. (2005). Invasion of the noxious weed Nicotiana glauca after an episodic flooding event in the arid zone of Australia. J. Arid Environ., 60(4): 531-545, DOI: 10.1016/j.jaridenv. 2004.07.015

Inderjit \& Duke, S.O. (2003). Ecophysiological aspects of allelopathy. Planta, 217(4): 529-539. DOI: $\quad 10.1007 / \mathrm{s} 00425-003-1054-z$. Available at: https://www.ncbi.nlm. nih.gov

Khoshkharam, M., Rezaei, A., Soleymani, A. \& Shahrajabian, M.H. (2010). Effects of tillage and residue management on yield components and yield of maize in second cropping after barley. Res. on Crops, 11(3): 659-666. Available at: Google Scholar

Mushtaq, W. \& Siddiqui, M.B. (2018). Allelopathy in Solanaceae plants. J.Plant Prot.Res., 58(1): 1-7, DOI: 10.24425/119113. Available at: https://www.plantprotection.pl

Nishida, N., Tamotsu, S., Nagata, N., Saito, C. \& Sakai, A. (2005). Allelopathic effects of volatile monoterpenoids produced by Salvia leucophylla: inhibition of cell proliferation and DNA synthesis in the root apical meristem of Brassica campestris seedlings. J.Chem.Ecol., 31(5): 1187-1203, DOI: 10.1007/s1 0886-005-4256-y. Available at: https://www.ncbi.clm.nih.gov

Norouzi, Y., Mohammadi, G.R. \& Nosratti, I. (2016). Effects of 


\section{ALLELOPATHIC EFFECTS OF TOBACCO ON CORN GROWTH AND GERMINATION}

different nitrogen levels on phytotoxicity of some allelopathic crops. Acta Agric.Slov., 107(1): 175182, DOI: 10.14720/aas.2016.107. 1.17

Nugroho, L.H. \& Verpoorte, R. (2002). Secondary metabolism in tobacco. PCTOC, 68: 105-125. Available at: https://link.springer.com

Ogbaji, P.O., Shahrajabian, M.H. \& Xue, $X$. (2013). Changes in germination and primarily growth of three cultivars of tomato under diatomite and soil materials in auto-irrigation system. Int.J.Biol., 5(3): 80-84, DOI: 10.5539/ijb.v5n3p80

Nekonam, S.M., Razmjoo, J., Kraimmojeni, H., Sharifnabi, B., Amini, H. \& Bahrami, F. (2014). Assessment of some medicinal plants for their allelopathic potential against redroot pigweed (Amaranthus retroflexus). J.Plant Prot.Res., 54(1): 90-95, DOI: 10.2478/jppr-2014-0014. Available at: https://www.agro.icm.edu.pl

Shahrajabian, M.H., Soleymani, A. \& Khoshkharam, M. (2017). Influence of green manuring from different cover crops and farm yard manures on quantitative and qualitative characteristics of forage corn in low input farming. Res. Crop Ecophysiol., 12(2): 62-68. Available at: https://www.roce.khuisf.ac.ir

Shahrajabian, M. H., Khoshkharam, M., Sun, W. \& Cheng, Q. (2019a). The effects of pretreatment factors on seed germination and seedling growth of anise (Pimpinella anisum L.). Middle East J.Sci., 5(1): 86-93 DOI: 10.23884/mejs.2019.5.1.09.

Shahrajabian, M.H., Sun, W. \& Cheng, Q. (2019b). Clinical aspects and health benefits of ginger (Zingiber officinale) in both traditional Chinese medicine and modern industry. Acta Agr.Scand.B-S P, 69(6): 546-556, DOI: $10.1080 / 09064710.2019 .1606$ 930

Shahrajabian, M.H., Sun, W. \& Cheng, Q. (2019c). A review of ginseng species in different regions as a multipurpose herb in traditional Chinese medicine, modern herbology and pharmacological science. J.Med. Plants Res., 13(10): 213-226, DOI: 10.5897/JMPR2019. 6731

Shahrajabian, M.H., Khoshkharam, M., Zandi, P., Sun, W. \& Cheng, Q. (2019d). Jujube, a super-fruit in traditional Chinese medicine, heading for modern pharmacological science. J.Med. Plants Stud., 7(4): 173-178.

Singh, A., Singh, D. \& Singh, N.B. (2009). Allelochemical stress produced by aqueous leachate of Nicotiana plumbaginifolia Viv. Plant Growth Regul., 58(2): 163-171, DOI: 10.1007/s10725-009-9364-1

Soleymani, A., Khajedin, A.A. \& Shahrajabian, M.H. (2011). Grain yield and yield components of corn (Zea mays L.) hybrids in response to planting dates in semi-arid region in Isfahan. Res. on Crops, 12(1): 4552. Available at: Google Scholar

Soleymani, A. \& Shahrajabian, M.H. (2012a). Effect of nitrogen fertilizer on ash, nitrate, organic carbon, protein and total yield of forage maize in semi-arid region of Iran. Res. on Crops, 13(3): 1030-1034. Available at: Google Scholar

Soleymani, A. \& Shahrajabian, M.H. (2012b). Forage yield and quality in intercropping of forage corn with different cultivars of berseem clover in different levels of nitrogen fertilizer. JFAE, 10(1): 602-604. Available at: Google Scholar

Soleymani, A. \& Shahrajabian, M.H. (2012c). Study of allelopathic effects of sesame (Sesamum indicum) on canola (Brassica napus) growth and germination. Intl.J.Agri. Crop Sci., 4(4): 183-186. Available at: http://pdf.semanticscholar.org

Soleymani, A., Khoshkharam, M. \& Shahrajabian, M.H. (2012a). Influence of green manures and crop residue management on yield and 


\section{KHOSHKHARAM, M.H. SHAHRAJABIAN, W. SUN, Q. CHENG}

yield components of silage corn. Res. on Crops, 13(3): 871-876. Available at: Google Scholar

Soleymani, A., Shahrajaban, M.H. \& Khoshkharam, M. (2012b). Effect of different fertility systems on fresh forage yield and qualitative traits of forage corn. Res. on Crops, 13(30): 861-865. Available at: Google Scholar

Soleymani, A. \& Shahrajabian, M.H. (2013). The effects of nitrogen fertilizer on ash, nitrate, organic carbon, protein and total yield of forage maize in semi arid region of Iran. Tech.J.Engin.App.Sci., 3(15): 1680-1684. Available at: Google Scholar

Soleymani, A., Shahrajabian, M.H. \& Khoshkharam, M. (2016). The impact of barley residue management and tillage on forage maize. Rom.Agric.Res., 33: 161167. Available at: https://www. cabdirect.org

Soleymani, A. \& Shahrajabian, M.H. (2018). Changes in germination and seedling growth of different cultivars of cumin to drought stress. Cecet.Agron. in Moldova, 1(173): 91-100, DOI: 10.2478/cerce-20180008

Stachon, W.J. \& Zimdahl, R.L. (1980). Allelopathic activity of Canada thistle (Cirsium arvense) in Colorado. Weed Sci., 28(1): 83-86, DOI: 10.1017/S004317450002782X.

Available at: https://www.cambridge. org

Yazdani, M. \& Bagheri, H. (2011). Allelopathic effect of tobacco (Nicotiana tabacum L.) on germination and early growth of soybean (Glycine max L.). Aust.J. Basic Appl.Sci., 5(11): 1178-1181. Available at: https://pdfs.semantic scholar.org 